\begin{tabular}{|l} 
Publiser \\
Mangoumal of
\end{tabular}$\quad \begin{aligned} & \text { Graduate Program Universitas Galuh } \\
& \text { Master Manajemen Studies Program }\end{aligned}$

\title{
PENGARUH GAYA KEPEMIMPINAN, MOTIVASI DAN DISIPLIN KERJA TERHADAP KINERJA PEGAWAI : STUDI PADA BADAN KELUARGA BERENCANA DAN PEMBERDAYAAN PEREMPUAN KABUPATEN GARUT
}

\author{
Wawan Setiawan ${ }^{1}$, Oyon Saryono ${ }^{2}$ \\ ${ }^{1}$ Program Studi Magister Manajemen Program Pascasarjana Universitas Galuh Ciamis \\ e-mail :wawan.cemonk@gmail.com \\ ${ }^{2}$ Dosen Program Studi Magister Manajemen Program Pascasarjana Universitas Galuh Ciamis
}

\author{
Article History : \\ Recieved 10 December 2016 \\ Recieved in revished form \\ 27 December 2016 \\ Acepted 8 Januari 2017 \\ Available offline 20 Januari 2017 \\ Available online 20 Januari 2017
}

Language Transcript :

Indonesia

Key Words :

Gaya Kepemimpinan

Motivasi

Disiplin Kerja

$B K B P P$

\begin{abstract}
Berdasarkan hasil observasi diketahui bahwa kinerja pegawai Badan Keluarga Berencana dan Pemberdayaan Perempuan (BKBPP) kabupaten Garut belum optimal hal ini diduga disebabkan oleh gaya kepemimpinan, Motivasi dan Disiplin Kerja yang kurang menunjang penyelenggaraan pelayanan program Keluarga Berencana (KB). Berdasarkan permasalahan tersebut, maka tujuan penelitian ini adalah untuk mengetahui : Pengaruh gaya kepemimpinan, motivasi dan disiplin kerja terhadap kinerja pegawai Badan Keluarga Berencana dan Pemberdayaan Perempuan (BKBPP) Kabupaten Garut.Dengan menggunakan metode survey (explanatory survey method) penelitian ini dilaksanakan yang disesuaikan dengan tujuan penelitian yang akan menjelaskan dan mengalisis pengaruh variable bebas (independent variable) terhadap variable terikat (dependent variable). Dengan demikian maka penelitian ini menjelaskan dan mengalisis pengaruh gaya kepemimpinan, motivasi dan disiplin kerja terhadap kinerja pegawai Badan KBPP Kabupaten Garut. Dalam penelitian ini yang dijadikan populasi adalah pegawai Badan Keluarga Berencana Kabupaten Garut sebanyak 300 orang. Berdasarkan jumlah populasi tersebut penulis menggunakan responden sebanyak 75 orang. Hasil penelitian tentang pengaruh gaya kepemimpinan, motivasi dan disiplin kerja pegawai terhadap kinerja pada badan KBPP kabupaten Garut menemukan bahwa terdapat pengaruh gaya kepemimpinan, motivasi, dan disiplin kerja terhadap kinerja pegawai. Artinya semakin baik gaya kepemimpinan, motivasi dan disiplin kerja maka kinerja pegawai BKBPP akan meningkat.
\end{abstract}

\section{PENDAHULUAN}

Kepemimpinan merupakan suatu topik bahasan yang klasik, namun tetap sangat menarik untuk diteliti karena sangat menentukan berlangsungnya suatu organisasi. Kepemimpinan itu esensinya adalah pertanggung jawaban.

Masalah kepemimpinan masih sangat baik untuk diteliti karena tiada habisnya untuk dibahas di sepanjang peradaban umat manusia. Terlebih pada zaman sekarang ini yang semakin buruk saja moral dan mentalnya. Ibaratnya, semakin sulit mencari pemimpin yang baik (good leader). Pemimpin yang baik sebenarnya pemimpin yang mau berkorban dan peduli untuk orang lain serta bersifat melayani. Tetapi, kenyataannya berbeda. Bila kita lihat sekarang para pemimpin kita, dari lapisan bawah sampai lapisan tertinggi, dari pusat 
hingga ke daerah daerah. Banyak pemimpin yang hadir dengan tanpa mencerminkan sosok pemimpin yang seharusnya, malah terlihat adanya pemimpin-pemimpin yang jauh dari harapan rakyat, tidak peduli dengan nasib rakyat bawah, dan hampir tidak pernah berpikir untuk melayani masyarakat. Karena kepemimpinan mereka lebih dilandasi pada keinginan pribadi dan lebih mengutamakan kepentingan kelompok. Gaya kepemimpinan diartikan sebagai perilaku atau cara yang dipilih dan dipergunakan pemimpin dalam mempengaruhi pikiran, perasaan, sikap, dan perilaku organisasinya (Nawawi, 2003:113). Gaya kepemimpinan adalah cara seorang pemimpin mempengaruhi perilaku bawahan, agar mau bekerjasama dan bekerja secara produktif untuk mencapai tujuan organisasi (Malayu, 2000:167).

Penelitian ini ditujukan untuk memperoleh informasi tentang faktor-faktor yang mempengaruhi terhadap peningkatan kinerja pegawai Badan KBPP kabupaten Garut dalam upaya meningkatkan kesertaan ber KB khususnya MKJP (metode kontrasepsi jangka panjang), melalui variable gaya kepemimpinan, motivasi dan disiplin kerja

\section{METOOLOGI}

Adapun metode penelitian yang digunakan adalah Metodologi Kuantitatif, diartikan sebagai metode penelitian yang digunakan untuk meneliti populasi atau sampel pada umumnya dilakukan secara random, pengumpulan data menggunakan instrumen penelitian, analisis data bersifat kuantitatif atau statistik dengan tujuan untuk menguji hipotesis yang telah ditetapkan (Sugiyono, $2007: 13$ ).

Penelitian dilaksanakan dari bulan Nopember 2015 sampai April 2016 di Badan Keluarga Berencana dan Pemberdayan Perempuan Kabupaten Garut, yang beralamatkan di jalan RSU dr Slamet
No 2 Garut. Keabsahan dan keajegan (reliabilitas) penelitian ini diuji dengan cara melakukan penyebaran angket kuesioner, wawancara dan dokumentasi, data dideskripsikan, dianalisis dan disimpulkan.

Desain penelitian dalam penelitian ini digunakan desain kuantitatif dengan pendekatan korelasional antar variabel, menurut Sudjana (1995:367). "Studi yang membahas hubungan antara variabel dikenal dengan nama analisis korelasi. Ukuran yang dipakai untuk mengetahui derajat hubungan terutama untuk data kuantitatif, dinamakan koefesien korelatif dan determinatif ". Sedangkan menurut Wahyudin (2003: 312) untuk menguji variabel beberapa rata-rata nilainya yang dilakukan oleh pihak yang berbeda dipergunakan uji $r$ dan $t$ test. Desain penelitian menggambarkan hubungan kausal variable Gaya Kepemimpinan (X1), Motivasi (X2), dan Disiplin Kerja (X3) terhadap Kinerja Pegawai (Y) sebagai berikut :

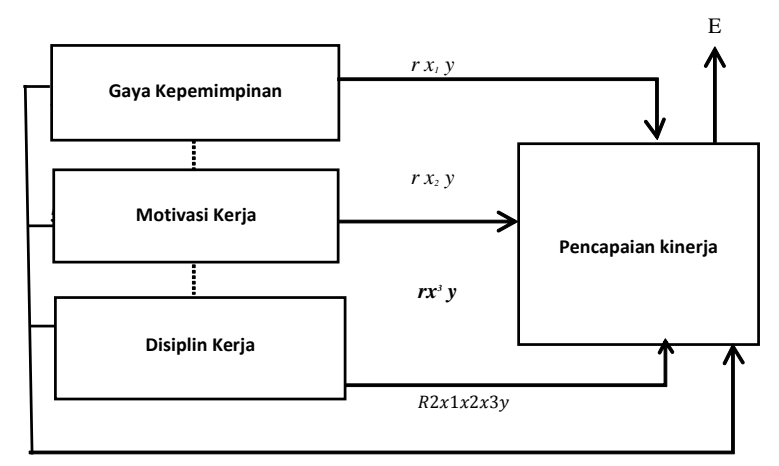

Gambar 1. Desain Penelitian

\section{HASIL DAN PEMBAHASAN}

1) Hasil Penelitian

\section{A. Pengaruh Gaya Kepemimpinan (X1) Terhadap Kinerja Pegawai (Y)}

Untuk membahas hipotesis pertama mengenai pengarus gaya kepemimpinan terhadap kinerja pegawai, maka peneliti akan menganalisis variabel X1 (gaya 
journal of managementReview

ISSN-P : 2580-4138 ISSN-E 2579-812X http://jurnal.unigal.ac.id/index.php/managementreview Volume 1 Number 1 Page (43-51)

kepemimpinan dan variabel Y (kinerja pegawai).

Interprestasi hasil pengujian melalui analisis korelasi dan regresi berganda untuk X1 (gaya kepemimpinan) terhadap Y (kinerja pegawai) dengan menggunakan SPSS versi 20,00, sebagai berikut

Tabel 1. Model Summary

\begin{tabular}{|l|c|r|r|c|}
\hline Model & $\mathrm{R}$ & $\mathrm{R}$ Square & $\begin{array}{c}\text { Adjusted R } \\
\text { Square }\end{array}$ & $\begin{array}{c}\text { Std. Error } \\
\text { of the } \\
\text { Estimate }\end{array}$ \\
\hline 1 & $.912^{\mathrm{a}}$ & .832 & .830 & 1.37497 \\
\hline
\end{tabular}

Dari perhitungan tersebut diketahui bahwa pengaruh antara variabel $\mathrm{X} 1$ (gaya kepemimpinan) dan variable $\mathrm{Y}$ (kinerja pegawai) diperoleh nilai produc moment sebesar 0,830. Dengan kata lain X1 berpengaruh terhadap $\mathrm{Y}$ sebesar $83 \%$ sedangkan sisanya sebesar $17 \%$ dipengaruhi oleh variabel lain yang tidak di teliti. Untuk koefisien korelasi yang ditemukan sebesar 0,830 , berdasarkan table 3.4 nilai 0,830 termasuk kategori sangat kuat. Jadi terdapat hubungan yang kuat antara variabel X1 (gaya kepemimpinan ) dengan variabel $\mathrm{Y}$ (kinerja pegawai). Setelah menganalisa hasil korelasi dan regresi berganda, maka dilakukan uji anova, dengan perolehan hasil sebagai berikut :

Tabel 2. ANOVA $^{\mathrm{a}}$

\begin{tabular}{|c|c|c|c|c|c|}
\hline Model & $\begin{array}{l}\text { Sum of } \\
\text { Squares }\end{array}$ & $d f$ & $\begin{array}{c}\text { Mean } \\
\text { Squar } \\
\mathrm{e}\end{array}$ & $F$ & Sig. \\
\hline \begin{tabular}{|l|l} 
& $\begin{array}{l}\text { Regressi } \\
\text { on }\end{array}$ \\
1 & $\begin{array}{l}\text { Residual } \\
\text { Total }\end{array}$ \\
\end{tabular} & $\begin{array}{l}682.577 \\
138.009 \\
820.587 \\
\end{array}$ & $\begin{array}{r}1 \\
73 \\
74 \\
\end{array}$ & $\begin{array}{r}682.5 \\
77 \\
1.891\end{array}$ & $\begin{array}{r}361.0 \\
49\end{array}$ & $.000^{b}$ \\
\hline
\end{tabular}

a. Dependent Variable: $Y$

b. Predictors: (Constant), $\mathrm{X} 1$

Dari table di atas diperoleh $\mathrm{F}$ hitung 361.049 dengan tingkat signifikansi $0,000<$ 0,005 , dan $\mathrm{F}$ tabel diperoleh dengan rumus (jumlah variable -1$)$, dan df $2(n-k-1)=73$, sehingga $\mathrm{F}$ hitung $>\mathrm{F}$ tabel $(361.049>$ $3.122)$ dan signifikansi $<0,005(0,000<$ 0,005), maka Ho ditolak, jadi dapat disimpulkan bahwa variabel gaya
kepemimpinan
berpengaruh
terhadap
kinerja.

Kriteria pengujian :

a. Jika $\mathrm{F}$ hitung $\leq \mathrm{F}$ tabel, maka Ho diterima.
b. Jika $\mathrm{F}$ hitung $\geq \mathrm{F}$ tabel, maka Ho ditolak

Untuk menguji kontansta dan variable dependen yaitu Y maka dilakukan kriteria uji koefisien korelasi dari variabel $\mathrm{X} 1$ dan Y yaitu :

Tabel 3. Coefficients ${ }^{\mathrm{a}}$

\begin{tabular}{|c|c|c|c|c|c|}
\hline \multirow[t]{2}{*}{ Model } & \multicolumn{2}{|c|}{$\begin{array}{l}\text { Unstandardized } \\
\text { Coefficients }\end{array}$} & \multirow{2}{*}{$\begin{array}{c}\text { Standar } \\
\text { dized } \\
\text { Coeffici } \\
\text { ents } \\
\text { Beta }\end{array}$} & \multirow[t]{2}{*}{$t$} & \multirow[t]{2}{*}{ Sig. } \\
\hline & $B$ & $\begin{array}{l}\text { Std. } \\
\text { Error }\end{array}$ & & & \\
\hline $\begin{array}{|ll|} & \text { (Cons } \\
1 & \text { tant) }\end{array}$ & 3.244 & .873 & & 3.718 & .000 \\
\hline X2 & .861 & .045 & .912 & 19.001 & .000 \\
\hline
\end{tabular}

a. Dependent Variable: $\mathrm{X} 1$

Berdasarkan hasil analisis regresi linier $(\mathrm{Y}=\mathrm{a}+\mathrm{b} 1 \mathrm{X} 1)$ dengan menggunakan fasilitas SPSS 20.00 pada analisa gaya kepemimpinan (X1) terhadap kinerja pegawai $(\mathrm{Y})$ diperoleh nilai $\mathrm{a}=3.244$ dan nilai $b$ sebesar 0,912. Berdasarkan nilai tersebut, diperoleh persamaan regresi yang menggambarkan skor ramalan kinerja pegawai berdasarkan gaya kepemimpinan sebagai berikut :

$$
\mathrm{Y}=\mathbf{3 . 2 4 4 + 0 , 9 1 2}(\mathbf{0 , 8 6 1})
$$

\section{B. Pengaruh Motivasi (X2) Terhadap Kinerja Pegawai (Y)}

Untuk membahas hipotesis kedua mengenai pengaruh motivasi terhadap kinerja pegawai, maka peneliti akan menganalisis variabel $\mathrm{X} 2$ (motivasi) dan variable $\mathrm{Y}$ (kinerja pegawai). Interprestasi hasil pengujian melalui analisis korelasi dan regresi berganda untuk X2 (motivasi) terhadap Y (kinerja pegawai) dengan menggunakan SPSS versi 20,00, sebagai berikut : 


\begin{tabular}{l} 
Tabel 4. Model Summary \\
\begin{tabular}{|l|c|r|r|r|}
\hline Model & $\mathrm{R}$ & $\mathrm{R}$ Square & $\begin{array}{c}\text { Adjusted R } \\
\text { Square }\end{array}$ & $\begin{array}{c}\text { Std. Error } \\
\text { of the } \\
\text { Estimate }\end{array}$ \\
\hline 1 & $.958^{\mathrm{a}}$ & .918 & .917 & .95847 \\
\hline
\end{tabular} \\
\hline
\end{tabular}

Dari perhitungan tersebut diketahui bahwa pengaruh antara variabel X2 (Motivasi) dan variabel Y (kinerja pegawai) diperoleh nilai produc moment sebesar 0,917. Dengan kata lain $\mathrm{X} 2$ berpengaruh terhadap $\mathrm{Y}$ sebesar 91,7\% sedangkan sisanya sebesar $8,3 \%$ dipengaruhi oleh variabel lain yang tidak di teliti. Untuk koefisien korelasi yang ditemukan sebesar 0,917 , berdasarkan tabel 3.4 nilai 0,917 termasuk kategori sangat kuat. Jadi terdapat hubungan yang tinggi antara variabel X2 (motivasi ) dengan variabel $\mathrm{Y}$ (kinerja pegawai). Setelah menganalisa hasil korelasi dan regresi berganda, maka dilakukan uji anova, dengan perolehan hasil sebagai berikut :

Tabel 5. ANOVA ${ }^{\mathrm{a}}$

\begin{tabular}{|c|c|c|c|c|c|}
\hline Model & $\begin{array}{c}\text { Sum of } \\
\text { Square } \\
s\end{array}$ & $\mathrm{df}$ & $\begin{array}{l}\text { Mean } \\
\text { Square }\end{array}$ & $\mathrm{F}$ & Sig. \\
\hline $\begin{array}{l}\text { Regressi } \\
\text { on }\end{array}$ & $\begin{array}{r}753.52 \\
5\end{array}$ & 1 & $\begin{array}{r}753.52 \\
5\end{array}$ & $\begin{array}{r}820.2 \\
46\end{array}$ & $.000^{b}$ \\
\hline 1 Residual & 67.062 & 73 & .919 & & \\
\hline Total & $\begin{array}{r}820.58 \\
7\end{array}$ & 74 & & & \\
\hline
\end{tabular}

a. Dependent Variable: $Y$

b. Predictors: (Constant), X2

Dari tabel di atas diperoleh $\mathrm{F}$ hitung 820.246 dengan tingkat signifikansi $0,000<$ 0,005 , dan $\mathrm{F}$ tabel diperoleh dengan rumus (jumlah variabel -1$)$, dan df $2(n-k-1)=73$, sehingga $\mathrm{F}$ hitung $>\mathrm{F}$ tabel $(820.246>$ $3.122)$ dan signifikansi $<0,005(0,000<$ 0,005), maka Ho ditolak, jadi dapat disimpulkan bahwa variabel motivasi berpengaruh terhadap kinerja. Untuk menguji kontansta dan variabel dependen yaitu Y maka dilakukan kriteria uji koefisien korelasi dari variable $\mathrm{X} 2$ dan $\mathrm{Y}$ yaitu :

Tabel 6. Coefficients ${ }^{\mathrm{a}}$
\begin{tabular}{|c|r|r|r|r|r|}
\hline Model & \multicolumn{2}{|c|}{$\begin{array}{c}\text { Unstandardized } \\
\text { Coefficients }\end{array}$} & $\begin{array}{c}\text { Standardi } \\
\text { zed } \\
\text { Coefficie } \\
\text { nts }\end{array}$ & $\mathrm{t}$ & Sig. \\
\cline { 2 - 4 } & \multicolumn{1}{|c|}{$\mathrm{B}$} & $\begin{array}{c}\text { Std. } \\
\text { Error }\end{array}$ & \multicolumn{1}{c|}{ Beta } & & \\
\hline $\begin{array}{c}\text { (Const } \\
1 \text { ant) } \\
\text { X3 }\end{array}$ & 2.133 & .618 & & 3.451 & .001 \\
\hline
\end{tabular}

a. Dependent Variable: $Y$

Berdasarkan hasil analisis regresi linier $(\mathrm{Y}=\mathrm{a}+\mathrm{b} 2 \mathrm{X} 2)$ dengan menggunakan fasilitas SPSS 20.00 pada analisa Motivasi (X2) terhadap kinerja pegawai (Y) diperoleh nilai $\mathrm{a}=2.133$ dan nilai $\mathrm{b}$ sebesar 0,958. Berdasarkan nilai tersebut, diperoleh persamaan regresi yang menggambarkan skor ramalan kinerja pegawai berdasarkan gaya kepemimpinan sebagai berikut :

$$
Y=2.133+0,958(0,907)
$$

\section{Pengaruh Disiplin Kerja (X3) Terhadap Kinerja Pegawai (Y)}

Untuk membahas hipotesis ketiga mengenai pengaruh disiplin kerja terhadap kinerja pegawai, maka peneliti akan menganalisis variabel X3 (disiplin kerja) dan variabel Y (kinerja pegawai). Interprestasi hasil pengujian melalui analisis korelasi dan regresi berganda untuk X3 (disiplin kerja) terhadap Y (kinerja pegawai) dengan menggunakan SPSS versi 20,00, sebagai berikut :

Tabel 7. Model Summary

\begin{tabular}{|l|r|r|r|r|}
\hline Model & $\mathrm{R}$ & $\mathrm{R}$ Square & $\begin{array}{c}\text { Adjusted R } \\
\text { Square }\end{array}$ & $\begin{array}{c}\text { Std. Error } \\
\text { of the } \\
\text { Estimate }\end{array}$ \\
\hline 1 & $.933^{\mathrm{a}}$ & .871 & .869 & 1.27605 \\
\hline
\end{tabular}

a. Predictors: (Constant), X3

Dari perhitungan tersebut diketahui bahwa pengaruh antara variabelX3 (disiplin kerja) dan variabel Y (kinerja pegawai) diperoleh nilai produc moment sebesar 0,869. Dengan kata lain X3 berpengaruh terhadap $\mathrm{Y}$ sebesar $86,9 \%$, sedangkan sisanya sebesar $14,1 \%$ dipengaruhi oleh variabel lain yang tidak di teliti. Untuk koefisien korelasi yang ditemukan sebesar 0,869 , berdasarkan tabel 
3.4 nilai 0,869 termasuk kategori kuat. Jadi terdapat hubungan yang kuat antara variabel X3 (disiplin kerja ) dengan variabel Y (kinerja pegawai). Setelah menganalisa hasil korelasi dan regresi berganda, maka dilakukan uji anova, dengan perolehan hasil sebagai berikut :

Tabel 8. ANOVA ${ }^{\mathrm{a}}$

\begin{tabular}{|l|c|r|r|r|r|}
\hline Model & $\begin{array}{c}\text { Sum of } \\
\text { Squares }\end{array}$ & df & $\begin{array}{c}\text { Mean } \\
\text { Square }\end{array}$ & F & Sig. \\
\hline $\begin{array}{l}\text { Regres } \\
\text { sion }\end{array}$ & 801.800 & 1 & $\begin{array}{r}801.80 \\
0\end{array}$ & $\begin{array}{r}492.4 \\
13\end{array}$ & $.000^{\mathrm{b}}$ \\
$\begin{array}{l}\text { Residu } \\
\text { al }\end{array}$ & 118.866 & 73 & 1.628 & & \\
$\quad$ Total & 920.667 & 74 & & & \\
\hline
\end{tabular}

a. Dependent Variable: $Y$

b. Predictors: (Constant), X3

Dari tabel di atas diperoleh $\mathrm{F}$ hitung 492.413 dengan tingkat signifikansi 0,000 < 0,005 , dan $\mathrm{F}$ tabel diperoleh dengan rumus (jumlah variabel -1$)$, dan df $2(n-k-1)=73$, sehingga $\mathrm{F}$ hitung $>\mathrm{F}$ tabel $(492.413>$ $3.122)$ dan signifikansi $<0,005(0,000<$ 0,005), maka Ho ditolak , jadi dapat disimpulkan bahwa variabel Disiplin kerja berpengaruh terhadap kinerja.

Untuk menguji kontansta dan variabel dependen yaitu Y maka dilakukan kriteria uji koefisien korelasi dari variable $\mathrm{X} 3$ dan Y yaitu :

Tabel 9. Coefficients ${ }^{\mathrm{a}}$

\begin{tabular}{|c|c|c|c|c|c|}
\hline \multirow[t]{2}{*}{ Model } & \multicolumn{2}{|c|}{$\begin{array}{l}\text { Unstandardized } \\
\text { Coefficients }\end{array}$} & \multirow{2}{*}{$\begin{array}{c}\begin{array}{c}\text { Standar } \\
\text { dized } \\
\text { Coeffici } \\
\text { ents }\end{array} \\
\text { Beta }\end{array}$} & \multirow[t]{2}{*}{$t$} & \multirow[t]{2}{*}{ Sig. } \\
\hline & $B$ & $\begin{array}{l}\text { Std. } \\
\text { Error }\end{array}$ & & & \\
\hline $\begin{array}{l}\text { (Consta } \\
\text { nt) }\end{array}$ & .970 & .823 & & $\begin{array}{l}1.1 \\
79\end{array}$ & 242. \\
\hline$x 3$ & .936 & .042 & .933 & $\begin{array}{r}22 . \\
190\end{array}$ & .000 \\
\hline
\end{tabular}

Berdasarkan hasil analisis regresi linier $(\mathrm{Y}=\mathrm{a}+\mathrm{b} 3 \mathrm{X} 3)$ dengan menggunakan fasilitas SPSS 20.00 pada analisa Motivasi (X2) terhadap kinerja pegawai (Y) diperoleh nilai $\mathrm{a}=0.970$ dan nilai $\mathrm{b}$ sebesar 0,933. Berdasarkan nilai tersebut, diperoleh persamaan regresi yang menggambarkan skor ramalan kinerja pegawai berdasarkan gaya kepemimpinan sebagai berikut :

$Y=0,970+0,936(0,936)$

\section{Pengaruh Gaya Kepemimpinan (X1), Motivasi (X2) dan Disiplin Kerja (X3) Terhadap Kinerja Pegawai (Y).}

Untuk membahas hipotesis keempat mengenai pengaruh gaya kepemimpinan (X1), Motivasi (X2) dan Disiplin Kerja (X3) terhadap kinerja pegawai (Y), maka peneliti akan menganalisis variabel gaya kepemimpinan (X1), motivasi (X2) dan disiplin kerja (X3) dan variabel kinerja pegawai (Y). Interprestasi hasil pengujian melalui analisis korelasi dan regresi berganda untuk X1,X2 dan X3 terhadap Y (kinerja pegawai) dengan menggunakan SPSS versi 20,00, sebagai berikut :

Tabel 10. Model Summary

\begin{tabular}{|l|c|r|r|r|}
\hline Model & $\mathrm{R}$ & $\mathrm{R}$ Square & $\begin{array}{c}\text { Adjusted } \\
\mathrm{R} \text { Square }\end{array}$ & $\begin{array}{c}\text { Std. Error of } \\
\text { the Estimate }\end{array}$ \\
\hline 1 & $.805^{\mathrm{a}}$ & .647 & .632 & 2.89624 \\
\hline
\end{tabular}

Dari perhitungan tersebut diketahui bahwa pengaruh antara variabel gaya kepemimpinan (X1), motivasi (X2) dan disiplin kerja (X3) dan variable Y (kinerja pegawai) diperoleh nilai produc moment sebesar 0,638. Dengan kata lain variabel gaya kepemimpinan (X1), motivasi (X2) dan disiplin kerja (X3) dan variable $\mathrm{Y}$ (kinerja pegawai) berpengaruh terhadap $\mathrm{Y}$ sebesar $63,8 \%$ sedangkan sisanya sebesar $36,2 \%$ dipengaruhi oleh variabel lain yang tidak di teliti. Untuk koefisien korelasi yang ditemukan sebesar 0,632 , berdasarkan table 3.4 nilai 0,632 termasuk kategori sedang. Jadi terdapat hubungan yang cukup antara variabel gaya kepemimpinan (X1), motivasi (X2) dan disiplin kerja (X3) dan variabel Y (kinerja pegawai) dengan variable $\mathrm{Y}$ (kinerja pegawai). Setelah menganalisa hasil korelasi dan regresi berganda, maka dilakukan uji anova, dengan perolehan hasil sebagai berikut : 
Tabel 11. ANOVA ${ }^{\mathrm{a}}$

\begin{tabular}{|c|c|c|c|c|c|}
\hline Model & $\begin{array}{l}\text { Sum of } \\
\text { Squares }\end{array}$ & $\mathrm{df}$ & $\begin{array}{l}\text { Mean } \\
\text { Square }\end{array}$ & $\mathrm{F}$ & Sig. \\
\hline $\begin{array}{l}\text { Regressi } \\
\text { on }\end{array}$ & 1093.157 & 3 & 364.386 & $\begin{array}{r}43 . \\
440\end{array}$ & $.000^{\mathrm{b}}$ \\
\hline $\begin{array}{ll}1 & \text { Residual }\end{array}$ & 595.563 & 71 & 8.388 & & \\
\hline Total & 1688.720 & 74 & & & \\
\hline
\end{tabular}

a. Dependent Variable: $Y$

b. Predictors: (Constant), X3, X2, X1

Dari tabel di atas diperoleh F hitung 43,440 dengan tingkat signifikansi $0,000<0,005$, dan $F$ tabel diperoleh dengan rumus (jumlah variable -1$)$, dan df $2(n-k-1)=73$, sehingga $\mathrm{F}$ hitung $>\mathrm{F}$ tabel $(43.440>$ 3.122 ) dan signifikansi $<0,005(0,000<$ 0,005), maka Ho ditolak, jadi dapat disimpulkan bahwa variable gaya kepemimpinan, motivasi dan disiplin kerja Disiplin kerja berpengaruh terhadap kinerja pegawai. Untuk menguji kontansta dan variabel dependen yaitu Y maka dilakukan kriteria uji koefisien korelasi dari variable X1,X2 dan X3 dan Y yaitu :

Tabel 12. Coefficients ${ }^{\mathrm{a}}$

\begin{tabular}{|c|c|c|c|c|c|}
\hline \multirow[t]{2}{*}{ Model } & \multicolumn{2}{|c|}{$\begin{array}{c}\text { Unstandardiz } \\
\text { ed } \\
\text { Coefficients }\end{array}$} & \multirow{2}{*}{\begin{tabular}{|c|}
$\begin{array}{c}\text { Standardi } \\
\text { zed } \\
\text { Coefficie } \\
\text { nts }\end{array}$ \\
Beta \\
\end{tabular}} & \multirow[t]{2}{*}{$\bar{t}$} & \multirow[t]{2}{*}{ Sig. } \\
\hline & $B$ & $\begin{array}{l}\text { Std. } \\
\text { Error }\end{array}$ & & & \\
\hline $\begin{array}{l}\text { (Con } \\
\text { stant) }\end{array}$ & 4.434 & 2.018 & & 2.197 & .031 \\
\hline $1 \times 1$ & .848 & .359 & .591 & 2.362 & .021 \\
\hline $\mathrm{x} 2$ & 1.393 & .270 & 1.028 & 5.164 & .000 \\
\hline X3 & .430 & .388 & .317 & 1.108 & .271 \\
\hline
\end{tabular}

Berdasarkan hasil analisis regresi linier $(\mathrm{Y}=\mathrm{a}+\mathrm{b} 1 \mathrm{X} 1+\mathrm{b} 2 \mathrm{X} 2+\mathrm{b} 3 \mathrm{X} 3) \quad$ dengan menggunakan fasilitas SPSS 20.00 pada analisa Motivasi (X2) terhadap kinerja pegawai $(\mathrm{Y})$ diperoleh nilai $\mathrm{a}=4.434$ dan nilai b1 sebesar 0,591,b2 1,028 dan b3 0,317 . Berdasarkan nilai tersebut , diperoleh persamaan regresi yang menggambarkan skor ramalan kinerja pegawai berdasarkan gaya kepemimpinan sebagai berikut :

$$
\begin{gathered}
Y=4.434+0,591(0,848)+ \\
1,028(1.393)+0,317(0,430)
\end{gathered}
$$

\section{E. Koefisien Determinasi $\left(\mathbf{R}^{2}\right)$}

Koefisien determinasi merupakan besaran yang menunjukkan besarnya variasi variabel dependen yang dapat dijelaskan oleh variable independennya. Dengan kata lain, koefisien determinasi ini digunakan untuk mengukur seberapa jauh variabelvariabel bebas dalam menerangkan variabel terikatnya. Nilai koefisien determinasi ditentukan dengan nilai adjusted $R$ square pada table 4.48 berikut ini :

Tabel 13. Model Summary

\begin{tabular}{|l|c|r|r|r|}
\hline $\begin{array}{l}\text { Mode } \\
\text { l }\end{array}$ & $\mathrm{R}$ & $\mathrm{R}$ Square & $\begin{array}{c}\text { Adjusted R } \\
\text { Square }\end{array}$ & $\begin{array}{c}\text { Std. Error of } \\
\text { the Estimate }\end{array}$ \\
\hline 1 & $.936^{\mathrm{a}}$ & .876 & .871 & 1.61766 \\
\hline
\end{tabular}

Hasil perhitungan regresi dapat diketahuibahwa koefisien determinasi (adjusted $R 2$ ) yang diperoleh sebesar 0,871. Hal ini berarti $87 \%$ variasi variabel kinerja pegawai dapat dijelaskan oleh variabel gaya kepemimpinan, motivasi dan disiplin kerja, sedangkan sisanya sebesar 13\% diterangkan oleh variabel lain yang tidak diajukan dalam penelitian ini.

\section{2) Hasil Pembahasan}

Berdasarkan hasil pengujian secara statistic dapat terlihat dengan jelas bahwa secara parsial (individu) semua variable bebas berpengaruh terhadap variable terikat. Pengaruh yang diberikan ketiga variabel bebas tersebut bersifat positif artinya semakin tinggi gaya kepemimpinan, motivasi dan disiplin kerja maka mengakibat kan semakin tinggi pula kinerja pegawai yang dihasilkan. Hasil tersebut sesuai dengan hipotesis yang diajukan. Hasil penelitian ini juga sesuai dengan hasil penelitian sebelumnya. Penjelasan dari masing-masing pengaruh variabel dijelaskan sebagai berikut : 


\section{A. Pengaruh Gaya Kepemimpinan terhadap Kinerja Pegawai}

Hasil pengujian hipotesis (H1) telah membuktikan terdapat pengaruh antara gaya kepemimpinan terhadap kinerja pegawai. Melalui hasil perhitungan yang telah dilakukan diperoleh nilai $\mathrm{t}$ hitung sebesar 16,594 dengan taraf signifikansi hasil sebesar 0,000 tersebut lebih kecil dari 0,05, dengan demikian Ha diterima dan Ho ditolak. Pengujian ini secara statistik membuktikan bahwa gaya kepemimpinan berpengaruh positif terhadap kinerja pegawai. Artinya bahwa ada pengaruh antara variabel gaya kepemimpinan terhadap kinerja pegawai di Badan Keluarga Berencana dan Pemberdayaan Perempuan Kabupaten Garut (KBPP). Hasil ini mendukung penelitian sebelumnya oleh (Suranta, 2002) yang menguji pengaruh gaya kepemimpinan terhadap kinerja karyawan dengan hasil analisis yaitu gaya kepemimpinan mempunyai pengaruh positif dan signifikan terhadap kinerja pegawai.

Sesuai teori Gaya kepemimpinan diartikan sebagai perilaku atau cara yang dipilih dan dipergunakan pemimpin dalam mempengaruhi pikiran, perasaan, sikap, dan perilaku organisasinya (Nawawi, 2003:113). Begitu pula gaya kepemimpinan adalah cara seorang pemimpin mempengaruhi perilaku bawahan, agar mau bekerjasama dan bekerja secara produktif untuk mencapai tujuan organisasi (Malayu, 2000:167).

\section{B. Pengaruh Motivasi terhadap Kinerja Pegawai}

Hasil pengujian hipotesis (H2) telah membuktikan terdapat pengaruh antara motivasi terhadap kinerja pegawai. Melalui hasil perhitungan yang telah dilakukan diperoleh nilai $t$ hitung sebesar 21,129 dengan taraf signifikansi hasil sebesar 0,000 tersebut lebih kecil dari 0,05 , yang berarti bahwa hipotesis dalam penelitian ini menerima Ha dan menolak Ho. Pengujian ini secara statistik membuktikan bahwa motivasi berpengaruh positif terhadap kinerja pegawai. Artinya bahwa ada pengaruh antara variabel motivasi terhadap kinerja pegawai di Badan Keluarga Berencana dan Pemberdayaan Perempuan Kabupaten Garut (BKBPP). Hasil ini mendukung penelitian sebelumnya oleh (Suharto dan Budi Cahyono, 2005) yang menyatakan bahwa ada pengaruh positif dan signifikan antara motivasi terhadap kinerja pegawai.

Mitchell dalam Winardi (2001:1) yaitu “ Motivasi mewakili proses-proses psikologikal, yang menyebabkan timbulnya, diarahkannya dan terjadinya presentasi kegiatan-kegiatan sukarela yang diarahkan kearah tujuan tertentu". Sedangkan Suryabrata (1998) mendefinisikan Motivasi sebagai " suatu keadaan tertentu dalam diri pribadi seseorang (individu) yang mendorong individu tersebut melakukan aktivitas tertentu guna mencapai suatu tujuan ".

\section{Pengaruh Disiplin Kerja terhadap Kinerja Pegawai}

Hasil pengujian hipotesis (H3) telah membuktikan terdapat pengaruh antara disiplin kerja terhadap kinerja karyawan. Melalui hasil perhitungan yang telah dilakukan didapat nilai $\mathrm{t}$ hitung sebesar 3,820dengan taraf signifikansi hitung sebesar 0,000 tersebut lebih besar dari 0,05, yang berarti bahwa hipotesis dalam penelitian ini menolak Ho dan menerima Ha, Pengujian ini secara statistik membuktikan bahwa disiplin kerja berpengaruh positif terhadap kinerja pegawai. Artinya bahwa ada pengaruh antara variabel disiplin kerja terhadap kinerja pegawai Badan KBPP Kabupaten Garut. Hasil ini mendukung penelitian sebelumnya oleh (Budi Setiyawan dan Waridin, 2006) .Menurut saydam (2000 : 23) menyatakan disiplin merupakan kemampuan untuk menguasai diri sendiri 
dan melaksanakan norma - norma yang berlaku dalam kehidupan, mentaati tata cara yang telah ditentukan dalam kehidupan, mentaati tata cara yang telah ditentukan dalam melaksanakan tugas dan tanggung jawab yang telah diserahkan kepada setiap orang sehingga dapat dijalankan dengan penuh kesadaran.

\section{Pengaruh Gaya Kepemimpinan, Motivasi dan Disiplin Kerja terhadap Kinerja Pegawai.}

Berdasarkan hasil analisis diperoleh kenyataan bahwa terdapat pengaruh yang positif dan signifikan antara variable gaya kepemimpinan (X1), Motivasi (X2) dan Disiplin Kerja (X3) terhadap Kineja Pegawai (Y). Hasil analisis menunjukan bahwa kinerja pegawai dipengaruhi oleh gaya kepemimpinan sebesar 0,591. Hal tersebut menunjukan bahwa terdapat pengaruh yang tinggi dari $\mathrm{X} 1$ dan $\mathrm{X} 2$ terhadap Y. Untuk menyatakan besar kecilnya kontribusi/sumbangan dari variable $\mathrm{X} 1$ dan $\mathrm{X} 2$ terhadap variable $\mathrm{Y}$, dapat dilihat dari perhitungan gaya kepemimpinan sebesar 0,591, Motivasi sebesar 1,028, Disiplin kerja sebesar 0,317 dan apa bila diprosentasekan adalah $87 \%$ sedangkan sisanya sebesar $13 \%$ dipengaruhi faktor lain yang tidak diteliti.Kinerja adalah hasil kerja baik secara kualitas maupun kuantitas yang dicapai oleh seseorang dalam melaksanakan tugas sesuai tanggung jawab yang diberikan (AA.Prabu.Mangkunagara, 2002:22). Pengertian kinerja menurut Sulistiyani(2003:223), kinerja seseorang merupakan kombinasi dari kemampuan, usaha, dan kesempatan yang dapat dinilai dari hasil kerjanya.

\section{SIMPULAN}

Berdasarkan pembahasan seluruh hasil penelitian yang sudah diuraikan sebelumnya, penulis dapat menarik kesimpulan sebagai berikut :
1. Gaya Kepemimpinan berpengaruh positif dan signifikan terhadap Kinerja pegawai. Artinya jika Gaya Kepemimpinan baik maka kinerja pegawai akan meningkat.

2. Motivasi berpengaruh signifikan terhadap kinerja pegawai. Artinya jika Motivasi tinggi maka kinerja pegawai akan meningkat.

3. Disiplin kerja berpengaruh signifikan terhadap kinerja pegawai. Artinya jika Disiplin kerja baik, maka kinerja pegawai akan meningkat.

4. Gaya Kepemimpinan, Motivasi dan Disiplin kerja berpengaruh signifikan terhadap kinerja pegawai. Artinya jika Gaya Kepemimpinan, Motivasi dan Disiplin kerja baik, maka kinerja pegawai akan meningkat.

\section{DAFTAR PUSTAKA}

A.A.Anwar Prabu Mangkunagara (2014). Evaluasi Kinerja SDM, Bandung : PT Refika Aditama,

Abdulhak, I. (2000) Strategi membangun Motivasi Dalam Pembelajaran Orang Dewasa,; Bandung.CV Andira.

Arikunto S. Manajemen Penelitian. 2000. Jakarta, Rineka Cipta.

Duwi Priyatno, 5 Jam Belajar Olah Data dengan SPSS 17, (CV Andi Yogyakarta :2009)

Furqon, Statistika Terapan Untuk Penelitian. 2001. Bandung , Alfabeta.

Hamalik, Oemar. Pengembangan Sumberdaya manusia: Manajemen Pelatihan Ketenaga Kerjaan Pendekatan Terpadu, 2000. Jakarta, Bumi Aksara.

Harbani Pasolong, Kepemimpinan Birokrasi, (bandung : 
journal of managementReview

ISSN-P : 2580-4138 ISSN-E 2579-812X http://jurnal.unigal.ac.id/index.php/managementreview Volume 1 Number 1 Page (43-51)

http://terasmakalah.blogspot.com/2011/

02/kepemimpinan-dalam-

manajemen-

Kartono, Kartini. Pemimpin dan

Kepemimpinan. 2002. Jakarta:

PT Rajawali Press.

Koontz, Harold et. al. Manajemen Jilid

2. 1996. Jakarta: Penerbit

Erlangga.

Nawawi, Hadari. Administrasi Pendidikan. 1987. Jakarta: CV Masagung.

Purwanto . Administrasi dan Supervisi Pendidikan. 2002. Bandung: PT Remaja Rosda Karya.

Rahardjo . Kepemimpinan Kepala Sekolah yang Bermutu. 2005. Bandung: Alqoprint.

Riyanto, Y. Medodologi Penelitian Pendidikan. 2012. Surabaya, SIC.

Rohiat. Jurnal Kajian Manajemen Pendidikan Formasi. 2000. Jakarta: UHAMKA.

Satori, Djam'an dan Komariah, Aan 2009. Metodologi Penelitian Kualitatif. Bandung: CV Alfabeta.

Sukmadinata, Nana Syaodih. 2006. Metode Penelitian Pendidikan. Bandung: PT Remaja Rosda Karya.

T. Hani Handoko, Manajemen edisi 2 Arief Furchan, Pengantar Penelitian dalam Pendidikan, (Yogyakarta : PustakaPelajar, 2004).

Thoha, Miftah. Kepemimpinan dalam Manajemen. 2001. Jakarta: PT Raja Grafindo Persada. 